\title{
PREVALENCE OF RECTOANAL INHIBITORY REFLEX IN CHAGASIC MEGACOLON
}

\author{
Simone CAVENAGHI', Otaviano Cardoso da Silva FELICIO², Luis Sergio RONCHI², \\ Geni Satomi CUNRATH², Marcelo Maia Caixeta de MELO² and João Gomes NETINHO²
}

\begin{abstract}
Background - Rectoanal inhibitory reflex is not always evident in patients with chagasic megacolon. This may be due to insufficient volumes of air used during insufflation for the manometric examination. Aims - To identify the volume of air necessary to induce rectoanal inhibitory reflex in patients with chagasic megacolon and to observe its prevalence in these individuals. Methods - Rectoanal inhibitory reflex in 39 patient with chagasic megacolon was studied by means of anorectal manometry using the balloon method. The balloon was insufflated using sequential volumes up to $300 \mathrm{~mL}$ to induce reflex. Results - Rectoanal inhibitory reflex was identified in $43.6 \%$ of the patients using a mean volume of $196 \mathrm{~mL}$ of insufflated air (standard error $=13.5$ ). Conclusion - Rectoanal inhibitory reflex can be induced in patients with chagasic megacolon when greater volumes of air are used.
\end{abstract}

HEADINGS - Megacolon. Chagas disease. Anal canal, physiology. Rectum, physiology. Defecation. Reflex. Manometry.

\section{INTRODUCTION}

The term megacolon is used to designate dilation and elongation of the colon independent of etiology ${ }^{(13)}$. Chagasic megacolon is a late manifestation of Chagas' disease caused by irreversible destruction of peripheral ganglion cells of the autonomous nervous system during the acute phase of the disease ${ }^{(12,13)}$. It is frequently identified in Brazil and other Latin America countries ${ }^{(2,6,14,20,22)}$.

The physiopathology of chagasic megacolon is still not well understood. Maybe for this reason there are so many techniques for the surgical treatment of chagasic colopathy. Important contributions have been provided by some authors trying to explain the functional mechanism of evacuation in megacolon ${ }^{(5,10)}$. The most accepted theory is the rectal dyskinesia in which lack of motor coordination of the peristalsis occurs resulting in a functional disorder between contractions of the rectum and relaxations of the internal sphincter of the anus that causes intestinal constipation $^{(9)}$.

Rectoanal inhibitory reflex (RAIR) is considered to play an important role in the mechanism of evacuation ${ }^{(8,16,21)}$. Morphologic alterations of RAIR components have been associated to anorectal dysfunctions, including intestinal constipation and anal incontinence ${ }^{(15,23)}$. Moreover, RAIR may be abnormal in Chagas' disease ${ }^{(3,9)}$, due to the absence of relaxation of the internal anal sphincter, however, rectal contractions are occasionally observed ${ }^{(11)}$. Some studies have used anorectal manometry in patients with chagasic megacolon, evaluating the anal pressures or correlating the rectal sensibility and the rectosphincter reflex ${ }^{(20)}$.
Hence, the pattern of RAIR in patients with chagasic megacolon remains controversial. RAIR demonstrates the integrity of the intramural nervous system in the anorectal area; whereas degeneration, to varying degrees, of the intramural plexus occurs in patients with chagasic megacolon. This suggests the existence of both normal plexus cells and completely destroyed nervous cells in these patients ${ }^{(20)}$. In this case, some doubts remain as to whether the number of normal nervous cells in the anorectal area is enough to trigger RAIR and as to the volume of air insufflation necessary to induce RAIR in a rectum dilated to due Chagas' disease ${ }^{(18)}$.

The objective of this paper was to study the prevalence of RAIR in patients with chagasic megacolon, evaluating the volume of insufflated air necessary to induce RAIR, since this is directly associated to the anorectal function in the evacuation process.

\section{METHODS}

The RAIR of 39 patients with chagasic megacolon consulted in the outpatient clinic of the Coloproctology Service of "Hospital de Base", Medical School (FAMERP) in São José do Rio Preto, SP, Brazil, between May 2005 and August 2006 were prospectively studied. A control group of 12 individuals, without history of lesions or anorectal surgery and suffering from intestinal constipation was also studied.

To diagnose the disease, the patients were submitted to the Machado Guerreiro test and contrasted radiological examinations of the colon (opaque enema study) performed in the imaging Department of "Hospital de Base".

'Service of Physiotherapy, Department of Neurological Sciences, "Hospital de Base", São José do Rio Preto Medical School, São José do Rio Preto, SP, Brazil. Discipline of Coloproctology, Department of Surgery, São José do Rio Preto Medical School, São José do Rio Preto, SP, Brazil.

Correspondence: PT Simone Cavenaghi - Rua Paraná, 66 - Boa Vista - 15025-140 - São José do Rio Preto, SP, Brazil. E-mail: sicavenaghi@ig.com.br 
Patients with negative Machado Guerreiro tests, radiological examinations without characteristics suggestive of megacolon, as well as those previously submitted to surgical treatment of the megacolon were excluded from the study.

Initially, the objective of this research was explained and patients gave their written consent. This study was approved by the Research Ethics Committee of the FAMERP.

A questionnaire was completed with information related to gender, age, race, period of constipation and frequency of evaluations.

\section{Anorectal manometry}

Both groups were submitted to anorectal manometry in the Anorectal Physiology Laboratory of the Coloproctology Service of "Hospital de Base" - FAMERP. Enema was performed for all patients 3 hours before the examination in order to eliminate any fecal vestiges in the rectal ampulla.

The manometry apparatus consists of a system of continuous perfusion of distilled water at a velocity of $25 \mathrm{~mL} /$ minute. The system is composed of an internationally standardized pneumo-hydraulic water perfusion pump with one to eight channels with the pressure measured by highly sensitive pressure transducers (Dynapac MPX 816). This apparatus is interfaced to a computerized system (IBMTM-PC) by means of commercially available software (Proctomaster ${ }^{\mathrm{TM}}$, version 6.0).

In this study, to evaluate the RAIR, an axially-distributed eightchannel catheter was used with holes spaced at $0.5 \mathrm{~cm}$ intervals and a balloon at its tip. The examination was performed with the patient in the left lateral decubitus position with the catheter positioned in the anal region and the internal pressure equal to the external pressure. The balloon was introduced into the channel so that the most proximal perfusion hole would register the intrarectal pressure, while if any perfusion holes were located out of the anal channel, they would register the atmospheric pressure. After the insertion of the catheter, the investigators waited for some minutes until the pressure stabilized.

To study RAIR, the balloon, which was positioned in the rectal ampulla, was rapidly insufflated with air and deflated. Initially a $60 \mathrm{~mL}$-syringe with sequential volumes of $15 \mathrm{~mL}$ was used and subsequently a $300 \mathrm{~mL}$-syringe with sequential volumes of $25 \mathrm{~mL}$ was employed. The response was considered positive when there was a graphically identified relaxation seen as a deflation below the resting anal pressure (RAP) line (Figure 1). The observed results were collected and analyzed using the aforementioned software.

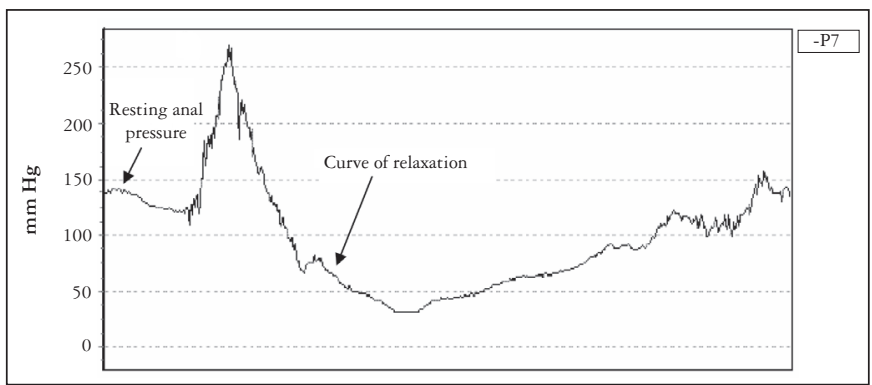

FIGURE 1. Rectoanal inhibitory reflex in patients with chagasic magacolon.

\section{Statistical analysis}

Data were submitted to statistical analysis using the KaplanMeier method with a cutoff point at $300 \mathrm{~mL}$ to study the volumes. Confidence intervals of $95 \%$ were used to estimate the means of continuous measurements and proportions for the quantitative variables. In all tests, a difference of 5\% was considered significant.

\section{RESULTS}

The mean age of the patients with megacolon was 64.6 years (SD = 9.7); women (61.5\%) and Caucasians (94.9\%) were predominant. In the control group, the mean age was 51.9 years $(\mathrm{SD}=9.9)$ and all individuals were Caucasians with $91.6 \%$ being men.

The mean frequency of evacuations of patients with chagasic megacolon was every 5 days and all patients had suffered from constipation for more than 5 years.

RAIR was detected in 17 (43.6\%) of the patients with chagasic megacolon with a mean volume of $196 \mathrm{~mL}$ of insufflated air being necessary for its induction (standard error $=13.5$ ), while in the control group the reflex was evidenced in $100 \%$ of individuals with a mean of $18.8 \mathrm{~mL}(\mathrm{SD}=6.8)$ of insufflated air.

Table 1 shows the probability of RAIR occurring in the chagasic megacolon at the respective volumes of insufflated air according to analysis using the Kaplan-Meier curve (Figure 2). A total of

TABLE 1. Probability of rectoanal inhibitory reflex occurring in patients with chagasic magacolon submitted to air insufflation to induce the reflex

\begin{tabular}{llll}
\hline Volume $(\mathrm{mL})$ & $\mathrm{n}$ & $P(\%)$ & $\mathrm{CI}$ \\
\hline 30 & 5 & 12.8 & 2.4 to 23.4 \\
45 & 1 & 15.4 & 4.0 to 26.8 \\
100 & 2 & 20.5 & 7.9 to 33.2 \\
125 & 1 & 23.0 & 10.0 to 36.3 \\
150 & 2 & 28.2 & 14.0 to 42.4 \\
175 & 1 & 30.8 & 16.3 to 45.3 \\
200 & 1 & 33.3 & 18.6 to 48.1 \\
225 & 2 & 38.4 & 23.2 to 53.7 \\
250 & 2 & 43.6 & 28.0 to 60.0 \\
\hline
\end{tabular}

Volume $(\mathrm{mL})=$ volume of induction of reflex in milliliters

$n=$ number of patients that presented with reflex

$P=$ probability of the occurrence of reflex

$\mathrm{Cl}=$ confidence intervals

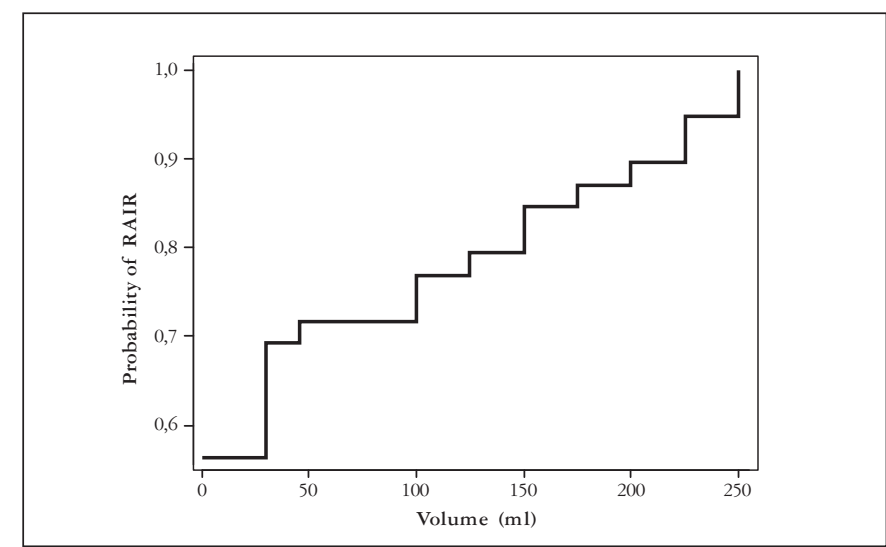

FIGURE 2. Kaplan-Meier curve showing the probability of rectoanal inhibitory reflex occurrence in the chagasic megacolon at the volumes of insufflated air 
15 to $300 \mathrm{~mL}$ of air was used; RAIR occurred with $30 \mathrm{~mL}$ of air in five $(29.4 \%)$ patients with a probability of $12.8 \%$ and with $60 \mathrm{~mL}$, as is usually utilized in the clinical practice, the probability was $15.4 \%$, while with $250 \mathrm{~mL}$, the probability was $43.6 \%$.

\section{DISCUSSION}

This study evaluated the RAIR in patients with chagasic megacolon using the balloon method and the probability of its occurrence increased $(43.6 \%)$ with greater volumes of air $(250 \mathrm{~mL})$. Air insufflation of up to $300 \mathrm{~mL}$ was used in the belief that, in the clinical practice, insufficient volumes are employed to induce RAIR in the chagasic megacolon. In individuals without the disease, RAIR is observed when the rectum is distended with small volumes of air that range from 15 to $30 \mathrm{~mL}^{(1,7)}$; in the control group of this study, RAIR was identified with a mean volume of $18.8 \mathrm{~mL}$ of air.

FANG et al. ${ }^{(3)}$ in a similar study, manometrically evaluated 27 patients with chagasic megacolon and detected RAIR in $26 \%$ of the cases. The volume of air necessary to trigger RAIR varied between 50 and $180 \mathrm{~mL}$. On the other hand, SANTOS ${ }^{(19)}$, studying the rectal-sphincter reflex in individuals without the disease, in patients with megacolon and normal rectum, and in those with megacolon and megarectum, observed that the reflex was preserved in chagasic patients independent of the size of the rectum. In this case, stimulation was achieved by balloon insufflation to induce reflex until the patient had an unsupportable desire to evacuate and then the balloon was expelled.

Anorectal manometry has been used to investigate the anorectal function in several clinical conditions, including in chagasic megacolon ${ }^{(1,3,4)}$. This examination, using the balloon insufflation method, makes an evaluation of RAIR possible ${ }^{(7)}$, but it may be absent in this disease, due to lesions of the myenteric and submucous plexuses ${ }^{(20)}$. SAAD ${ }^{(18)}$ reported that during the manometric examination in patients with megarectum, the absence of the reflex with normal distention volumes of the rectal balloon may be related to an incapacity to distend the dilated rectum and not due to lesions of the myenteric plexus. The finding in this study may be related to greater volumes that distend the rectum and relax the internal anal sphincter.

The exact mechanism of the neural damage in Chagas' disease must be elucidated as well as the physiopathological process by which neural destruction provokes visceral dilation ${ }^{(17)}$. However, it is recognized that the degeneration of the intrinsic nervous system occurs at differing degrees, with the non-dilated segments of the colon presenting the greatest percentage of preserved myenteric plexus ${ }^{(20)}$.

Few studies have investigated the physiology of the chagasic megacolon correlated with RAIR. Furthermore, standardization of the volume necessary to trigger this reflex has been rarely investigated. In this study, a high probability of the occurrence of reflex was observed with volumes greater than those adopted in the clinical practice for individuals without the disease. It is still necessary to understand why some patients with dilated rectum present with inhibited reflexes and others do not. Moreover, some patients with slightly dilated rectums do not present with RAIR. The main hypothesis is that the degree of plexus degeneration is not correlated with the anatomical changes. Thus, further studies to better understand the physiopathology of the chagasic megacolon are necessary.

In view of these results, it is suggested that investigations of RAIR should always be performed with balloon air insufflation using up to $300 \mathrm{~mL}$ of air in patients with chagasic megacolon, otherwise the doubt will remain to whether the patient presents with reflex or does not.

\section{CONCLUSION}

This study showed that RAIR was identified in approximately $50 \%$ of the patients with chagasic megacolon with greater volumes of air in rectal balloons being necessary to induce the reflex.

Cavenaghi S, Felicio OCS, Ronchi LS, Cunrath GS, Melo MMC, Netinho JG. Prevalência do reflexo inibitório retoanal no megacólon chagásico. Arq Gastroenterol. 2008;45(2):128-31.

RESUMO - Racional - O reflexo inibitório retoanal nem sempre é evidente nos pacientes com megacólon chagásico. Acredita-se que isso ocorra devido à utilização de volumes insuficientes de insuflação de ar, ao exame manométrico, para induzi-lo. Objetivo - Quantificar a média de volume de ar necessário para induzir o reflexo inibitório retoanal em pacientes com megacólon chagásico e verificar sua prevalência. Métodos - Estudou-se o reflexo inibitório retoanal em 39 pacientes com megacólon chagásico por meio da manometria anorretal, utilizando-se o método do balão. Para indução do reflexo foram insuflados volumes seqüenciais de até $300 \mathrm{~mL}$ de ar. Resultados - O reflexo inibitório retoanal foi encontrado em 43,6\% dos pacientes, com média de ar insuflado de 196 mL (erro padrão =13,5). Conclusão - O reflexo inibitório retoanal pode ser induzido em pacientes com megacólon chagásico, quando utilizados maiores volumes de insuflação de ar.

DESCRITORES - Megacolo. Doença de Chagas. Canal anal, fisiologia. Reto, fisiologia, Defecação. Reflexo. Manometria. 


\section{REFERENCES}

1. Baldez JR. Achados manométricos nas doenças ano reto cólicas. Rev Bras Coloproctol. 2004;24:10-4.

2. Corbett CE, Ribeiro Jr U, Prianti MG, Habr-Gama A, Okumura M, Gama-Rodrigues J. Cell-mediated immune response in megacolon from patients with chronic Chagas' disease. Dis Colon Rectum. 2001;44:993-8.

3. Fang CB, Klug WA, Aguida HA-C, Ortiz JA, Capelhuchnick P. Avaliação das pressões anais em doentes com megacólon chagásico. Rev Bras Coloproctol. 1998;18:173-7.

4. Gang Y. What is the desirable stimulus to induce the rectoanal inhibitory reflex? Dis Colon Rectum. 1995;38:60-3.

5. Gaston EA. Physiology of fecal continence. Surg Gynecol Obstet. 1948;87:280-90.

6. Gattuso JM, Kamm MA, Talbot IC. Pathology of idiopathic megarectum and megacolon. Gut. 1997;41:252-7.

7. Góes RN, Simons AJ, Masri L, Beart RW Jr. Gradient of pressure and time between proximal anal canal and high-pressure zone during internal anal sphincter relaxation: its role in the fecal continence mechanism. Dis Colon Rectum. 1995;38:1043-6.

8. Gowers WR. The automatic action of the sphincter ani. Proc R Soc Lond. 1877;26:77-84.

9. Habr-Gama A, Raia A, Corrêa-Neto A. Motility of the sigmoid colon and rectum. Contribution to the physiopathology of megacolon in Chagas' disease. Dis Colon Rectum. 1971;14:291-304.

10. Hurst AF, Rake GH. Achalasia of the cardia. Q J Med. 1930;23:491-509.

11. Jorge JMN, Wexner SD. Anorectal manometry: techniques and clinical applications. South Med J. 1993;86:924-31

12. Lins-Neto MAF. Operação de Duhamel modificada com anastomose colorretal imediata para o tratamento do megacólon chagásico. Técnicas e resultados. Rev Bras Coloproctol. 1999;19:263-6.

13. Moreira H, Rezende JM, Sebba F, Azevedo IF, Leite ACA, Soares EP. Megacolo chagásico. Rev Bras Coloproctol. 1983;3:152-62.

14. Netinho JG, Cunrath GS, Ronchi LS. Rectosigmoidectomy with ileal loop interposition a new surgical method for the treatment of chagasic megacolon. Dis Colon Rectum. 2002;45:1387-92.
15. Netinho JG, Ayrizono MLS, Coy CSR, Fagundes JJ, Góes JRN. Amplitude and recovery velocity of relaxation induced by rectoanal inhibitory reflex and its importance for obstructive evacuation. Arq Gastroenterol. 2005;42:19-23.

16. O'Riordain MG, Molloy RG, Gillen P, Horgan A, Kirwan WO. Rectoanal inhibitory reflex following low stapled anterior resection of the rectum. Dis Colon Rectum. 1992;35:874-8

17. Ribeiro Jr U, Safatle-Ribeiro AV, Habr-Gama A, Gama-Rodrigues JJ, Sohn J, Reynolds JC. Análise das alterações do óxido nítrico em pacientes com megacólon chagásico. Rev Bras Coloproctol. 1998;18:52-7.

18. Saad RC. Eletromanometria anorretal. In: Amaro JL, Haddad JM Trindade JCS Ribeiro RM, editores. Reabilitação do assoalho pélvico. São Paulo: Segmentofarma; 2005. p. 277-83.

19. Santos Jr JMC. Estudo comparativo da sensibilidade retal e do reflexo reto-esfincteriano entre pacientes chagásicos com megacólon e reto não dilatado, com megacólon e megarreto [dissertação]. Ribeirão Preto: Faculdade de Medicina de Ribeirão Preto, Universidade de São Paulo; 1977.

20. Santos Jr JCM. Megacólon - parte II: doença de Chagas. Rev Bras Coloproctol. 2002;22:266-77.

21. Shafik A, El-Sibai O, Ahmed I. Parasympathetic extrinsic reflex: role in defecation mechanism. World J Surg. 2002;26:737-40.

22. Sterin-Borda L, Goin JC, Bilder CR, Iantorno G, Hernando AC, Borda E. Interaction of human chagasic IgG with human colon muscarinic acetylcholine receptor: molecular and functional evidence. Gut. 2001;49:699-705.

23. Zbar A, Aslam M, Gold DM, Gatzen C, Gosling A, Kmiot WA. Parameters of the rectoanal inhibitory reflex in patients with idiopathic fecal incontinence and chronic constipation. Dis Colon Rectum. 1998;41:200-8. 